\title{
Facility Management as Part of an Integrated Design of Civil Engineering Structures
}

\author{
Ivan Hyben, Peter Podmanický \\ Technical University of Košice \\ Civil Engineering Faculty, Institute of Technology and Management in Civil Engineering \\ e-mail: ivan.hyben@tuke.sk, peter.podmanicky@tuke.sk
}

\begin{abstract}
The present article deals about facility management, as still relatively young component of an integrated planning and design of buildings. Attention is focused on the area of the proposal, which can greatly affect to amount of future operating costs. Operational efficiency has been divided into individual components and satisfaction with the solution of buildings already constructed was assessed by workers, who are actually dedicated facility management in these organizations. The results were then assessed and evaluated through regression analysis. The aim of this paper is to determine to what extent is desired update project documentation of new buildings from the perspective of facility management.
\end{abstract}

Key words: facility management, integrated design, life cycle of buildings, operational efficiency

\section{Introduction}

Our interest is to keep low operating costs and high utility value, thus we can talk about the high operational efficiency of buildings $[1,2$,$] . We know that the operational efficiency (OE)$ of buildings can be defined through space and layout, materials and construction and technical equipment of the objects [3]. Facility management (FM) is in a position, where it has the possibility influence $\mathrm{OE}$ of the planned object, through cooperation with a team of designers already when designing the building. OE unfortunately is not an exact parameter that could be accurately measured. Making process of the project documentation presents a number of decisions that are related to these areas, thus directly affect to OE of building structure [4]. These decisions can be defined and described in terms of the FM. To enable us to define the contribution of FM due to the OE of buildings, we must first define the satisfaction of facility managers with those solutions of structures that are already standing. It is possible then expressed overall satisfaction with the solution of structures from the perspective of facility managers, and we can define the possibility of an increase OE. 


\section{Space and layout}

One of the most important elements of the organization in the civil structure is the workplace. Work function has a strategic importance for the organization. Quality of work is a precondition for creating higher added value. Our interest is about creating optimal layout of workplaces and relationships of different departments, on the basis of defining the needs and requirements of the organization, resulting from the organizational structure of the organization in fulfilling its spatial standards [5]. Space requirements and other relevant criteria of functioning of the organization are acquired by facility manager in consultation and interviews with senior executives, technicians and employees. Facility manager have to create idea, from the information overview of the work within departments of each segment of the organization, reciprocity and needs between departments in the organizational structure. In spatial planning, the emphasis is on flexibility of the environment, which is an essential requirement of a modern organization with the rapid pace of development and changing space requirements [6]. In practice as major problem is little flexibility and variability in space, especially in the administrative part of individual buildings. It is also necessary to mention the possibility of applying new types of workplaces (listed in publications [7 \& 5), that in this area we have available. Their formation was involved in an international architectural firm active in leading engineering and architectural consulting services - DEGW (AECOM company) and company focused on consulting, testing and research services in the construction and related industries - BRE (Building Research Establishment Ltd.).

\section{Materials and construction}

Choosing the appropriate material base for the building structure is essential for the definition of operating costs, particularly in relation to the technical requirements imposed on them. The most striking element that influences the level of operating costs is a facade solution of building structure, since we have different kinds of solutions and types of elements, and can be the solution more or less financially burdensome for the company. Then there is the composition of plaster mixtures and floor structures, the cost of heating, which comprise the bulk of operating costs, are defined mainly through peripheral structure. In general, it should be that our aim is to don 't have unnecessarily too much differentiated range of materials and components, and selected elements should be used with caution. Quality of the proposal materially design is provide by a result of experiences of the individual participating designers. The solution should emerge as a result of a wider dialogue and a consensus. Great attention should be paid to peripheral structures that are in contact with the exterior, as these largely predetermine the amount of operating costs, the cost of heating represent a significant part of all operating costs.

The most significant aspect in terms of material construction solution remains facade. Available cavity facades provide, for example option to save the entire cabling for information technology, which can without causing the user to complement, respectively reinstall. Because this intermediate space is protected against the weather does not constitute transitions cables problem. Facility manager with the architect / designer should participate in the evaluation of simulations of individual variants[8]. 


\section{Technical equipment}

Between technical equipment and ensuring of building structures we include: heating equipment, health equipment, air conditioners and refrigeration equipment, heavy electrical, low voltage installations and lighting equipment. The aim is not to have over dimensioned technical equipment of object, which is the task of the various professions. Facility manager can contribute his experiences in the location of individual elements of the systems by virtue of their operation and maintenance. Alternatively regarding life and specification of individual elements based on their experiences. It is necessary to note the experience of facility manager and especially the competency that has, to avoid unnecessary conflicts within the project team. Participation of facility manager is evident mainly in optimization of suitable types, including their location, whereas in terms of operating costs, should be conversant with possible solutions of building structure.

\section{Defining the operational efficiency of buildings by a regression analysis}

To define the $\mathrm{OE}$ of buildings was used regression analysis, through analysis of available data. Regression analysis examines the relationship between the quantitative statistical characteristics [9]. While the correlation analysis is studied "only" the existence of dependence (correlation) characters, in regression analysis "already" determined the shape dependence [10]. Regression analysis is among the statistical methods used for estimating relationships between variables. Include many techniques for modeling and analyzing several variables, when the focus is on defining the relationship between a dependent variable, and one or more independent variables. More precisely, regression analysis helps us understand how changing the value of the dependent variable, while the other independent variables are fixed. Regression analysis is used in an enlarged extent in the prediction and forecasting, is also used to understand the impact of independent variables, to the problem and their relationship to the dependent variables. In limited cases, may be used in the derivation of causal relationships between dependent and independent variables. However, this can lead to false relationships and dependencies, so it is recommended in this case great caution [11].

Output of regression analysis depends on the form of data, the actual process of evaluation and access which we choose. Although the evaluation process data, through regression analysis generally known, often depends on knowledge and access to the method and processes, which require evaluation. Sometimes the wrong choice of access, especially on issues of causality, can result to not just optimal results [12 \& 13].

Based on these findings were interviewed 32 respondents from the field of FM which was led dialogue and also was filling out the questionnaire, focusing on issues of OE of buildings. Assessments are subjective and bind to different types of multipurpose buildings, including department stores, office buildings, as well as objects that are used to manufacture and storage of different types of products, including their administrative parts. The survey was conducted between 2012 and 2014. 


\subsection{The operating efficiency of buildings after the first year of use}

Results can be defined for two points, one that is itself performance of buildings after the first year of use - from final inspection, and secondly representation of $\mathrm{OE}$ in the life cycle of buildings. The overall evaluation of the results, we need to adjust and define the OE of the final value to the value 1 . The results are the most reliable according to the value of reliability in linear, second degree polynomial and the exponential function.

Table 1: The OE of buildings after the first year of use in terms of space layout solution

\begin{tabular}{|c|c|c|c|c|}
\hline \multicolumn{4}{|c|}{ Space layout solution } \\
$\begin{array}{c}\text { Regression } \\
\text { function }\end{array}$ & $\begin{array}{c}\text { The equation of regression } \\
\text { function }\end{array}$ & $\begin{array}{c}\text { Reliability } \\
\text { value } \mathrm{R}\end{array}$ & $\begin{array}{c}\text { Value } \\
\mathrm{y}(\mathrm{X}=1) \\
(\%)\end{array}$ & $\begin{array}{c}\text { Average } \\
\text { value } \\
\mathrm{y}(\mathrm{X}=1) \\
(\%)\end{array}$ \\
\hline Linear & $\mathrm{y}=91,273-0,144 \mathrm{x}$ & 0,269 & 91,129 & \\
\cline { 1 - 3 } $\begin{array}{c}\text { Second degree } \\
\text { polynomial }\end{array}$ & $\mathrm{y}=90,696-0,105 \mathrm{x}-0,0004 \mathrm{x}^{2}$ & 0,271 & 90,590 & \multirow{2}{*}{90,91} \\
\cline { 1 - 3 } Exponential & $\mathrm{y}=91,201 \mathrm{e}^{-0,002 \mathrm{x}}$ & 0,275 & 91,019 & \\
\hline
\end{tabular}

Table 2: The OE of buildings after the first year of use in terms of materials and cosntruction

\begin{tabular}{|c|c|c|c|c|}
\hline \multirow{2}{*}{$\begin{array}{c}\text { Regression } \\
\text { function }\end{array}$} & $\begin{array}{c}\text { The equation of regression } \\
\text { function }\end{array}$ & $\begin{array}{c}\text { Reliability } \\
\text { value } \mathrm{R}\end{array}$ & $\begin{array}{c}\text { Value } \\
\mathrm{y}(\mathrm{X}=1) \\
(\%)\end{array}$ & $\begin{array}{c}\text { Average } \\
\text { value } \\
\mathrm{y}(\mathrm{X}=1) \\
(\%)\end{array}$ \\
\hline Linear & $\mathrm{y}=91,126-0,175 \mathrm{x}$ & 0,219 & 90,951 & \\
\cline { 1 - 3 } $\begin{array}{c}\text { Second degree } \\
\text { polynomial }\end{array}$ & $\mathrm{y}=90,092-0,106 \mathrm{x}-0,0007 \mathrm{x}^{2}$ & 0,222 & 89,985 & \multirow{2}{*}{90,55} \\
\hline Exponential & $\mathrm{y}=90,903 \mathrm{e}^{-0,002 \mathrm{x}}$ & 0,218 & 90,721 & \\
\hline
\end{tabular}

Table 3: The OE of buildings after the first year of use in terms of technical equipment

\begin{tabular}{|c|c|c|c|c|}
\hline \multicolumn{5}{|c|}{ Technical equipment solution } \\
\hline $\begin{array}{l}\text { Regression } \\
\text { function }\end{array}$ & $\begin{array}{c}\text { The equation of regression } \\
\text { function }\end{array}$ & $\begin{array}{l}\text { Reliability } \\
\text { value } R\end{array}$ & $\begin{array}{c}\text { Value } \\
\mathrm{y}(\mathrm{X}=1) \\
(\%)\end{array}$ & $\begin{array}{c}\text { Average } \\
\text { value } \\
\text { y }(X=1) \\
(\%)\end{array}$ \\
\hline Linear & $y=94,76-0,2659 x$ & 0,581 & 94,494 & \multirow{3}{*}{95,03} \\
\hline $\begin{array}{l}\text { Second degree } \\
\text { polynomial }\end{array}$ & $y=96,072-0,3531 x+0,0009 x^{2}$ & 0,587 & 95,720 & \\
\hline Exponential & $y=95,171 e^{-0,003 x}$ & 0,590 & 94,885 & \\
\hline
\end{tabular}


Theoretical processing of the results is dependent on our perception and the approach adopted. OE can be defined in such a way that individual areas are equal, as to the effect on performance of the object itself, or one of the areas is more or less dominant, it is also possible to consider the fact that we are entering other parameters in the actual performance evaluation. If we interpret the results simply and generalizing, so it can be concluded that the most accurate results in terms of regression analysis and reliability values, are in the technical ensuring of buildings, less certainty in the interpretation of results is spatially and material design, from this perspective, it is clear that the results can be varied and depend on the evaluation alone solutions individual buildings, and these may vary significantly.

If we are defined respondents satisfaction with the solutions of individual areas, as a satisfaction with the solution itself, and therefore as OE itself, so the value of the first year of use buildings for each area are follows: in space layout is around $91 \%$ in the field of materials and construction is equally around $91 \%$, and building technology is approximately at $95 \%$.

\subsection{Operational efficiency in the life cycle of buildings}

Another output is to define the operational efficiency curves for different areas in the life cycle of buildings. In this case, are taken into account the average values, defined are as follows:

Table 4: OE of buildings in their life cycle in terms of space layout

\begin{tabular}{|c|c|c|c|c|c|c|c|c|}
\cline { 2 - 10 } \multicolumn{1}{c|}{} & \multicolumn{7}{c|}{ Space layout solution } \\
\hline Age of buildings & $\begin{array}{c}\mathrm{x} \\
\text { (years) }\end{array}$ & 1 & 5 & 10 & 20 & 30 & 40 & 50 \\
\hline Linear function & $\mathrm{y} 1(\%)$ & 91,13 & 90,56 & 89,84 & 88,40 & 86,97 & 95,53 & 84,09 \\
\hline $\begin{array}{c}\text { Second degree } \\
\text { polynomial }\end{array}$ & $\mathrm{y} 2(\%)$ & 90,59 & 90,16 & 89,60 & 88,42 & 87,16 & 85,82 & 84,40 \\
\hline Exponential function & $\mathrm{y} 3(\%)$ & 91,02 & 90,29 & 89,39 & 87,62 & 85,88 & 84,18 & 82,51 \\
\hline Average value & $\mathrm{y} \mathrm{( \% )}$ & 90,91 & 90,33 & 89,61 & 88,15 & 86,67 & 85,18 & 83,67 \\
\hline
\end{tabular}

Table 5: OE of buildings in their life cycle in terms of materials and construction solution

\begin{tabular}{|c|c|c|c|c|c|c|c|c|}
\cline { 2 - 10 } \multicolumn{1}{c|}{} & \multicolumn{7}{c|}{ Materials and construction solution } \\
\hline Age of buildings & $\begin{array}{c}\mathrm{x} \\
\text { (years) }\end{array}$ & 1 & 5 & 10 & 20 & 30 & 40 & 50 \\
\hline Linear function & $\mathrm{y} 1(\%)$ & 90,95 & 90,25 & 89,38 & 87,63 & 85,89 & 84,14 & 82,40 \\
\hline $\begin{array}{c}\text { Second degree } \\
\text { polynomial }\end{array}$ & $\mathrm{y} 2(\%)$ & 89,99 & 89,55 & 88,96 & 87,69 & 86,29 & 84,74 & 83,05 \\
\hline Exponential function & $\mathrm{y} 3(\%)$ & 90,72 & 90,00 & 89,10 & 87,34 & 85,60 & 83,91 & 82,24 \\
\hline Average value & $\mathrm{y}(\%)$ & 90,55 & 89,93 & 89,15 & 87,55 & 85,93 & 84,26 & 82,56 \\
\hline
\end{tabular}


Table 6: OE of buildings in their life cycle in terms of technical equipment solution

\begin{tabular}{|c|c|c|c|c|c|c|c|c|}
\cline { 2 - 10 } \multicolumn{1}{c|}{} & \multicolumn{7}{c|}{ Technical equipment solution } \\
\hline Age of buildings & $\begin{array}{c}\mathrm{x} \\
\text { (years) }\end{array}$ & 1 & 5 & 10 & 20 & 30 & 40 & 50 \\
\hline Linear function & $\mathrm{y} 1(\%)$ & 94,49 & 93,43 & 92,10 & 89,44 & 86,78 & 84,12 & 81,47 \\
\hline $\begin{array}{c}\text { Second degree } \\
\text { polynomial }\end{array}$ & $\mathrm{y} 2(\%)$ & 95,72 & 94,33 & 92,63 & 89,37 & 86,29 & 83,39 & 80,67 \\
\hline Exponential function & $\mathrm{y} 3(\%)$ & 94,89 & 93,75 & 92,35 & 89,62 & 86,97 & 84,39 & 81,90 \\
\hline Average value & $\mathrm{y}(\%)$ & 95,03 & 93,84 & 92,36 & 89,48 & 86,68 & 83,97 & 81,34 \\
\hline
\end{tabular}

The general view during the OE of buildings in their life cycle can be seen from various points of view in the following figure:

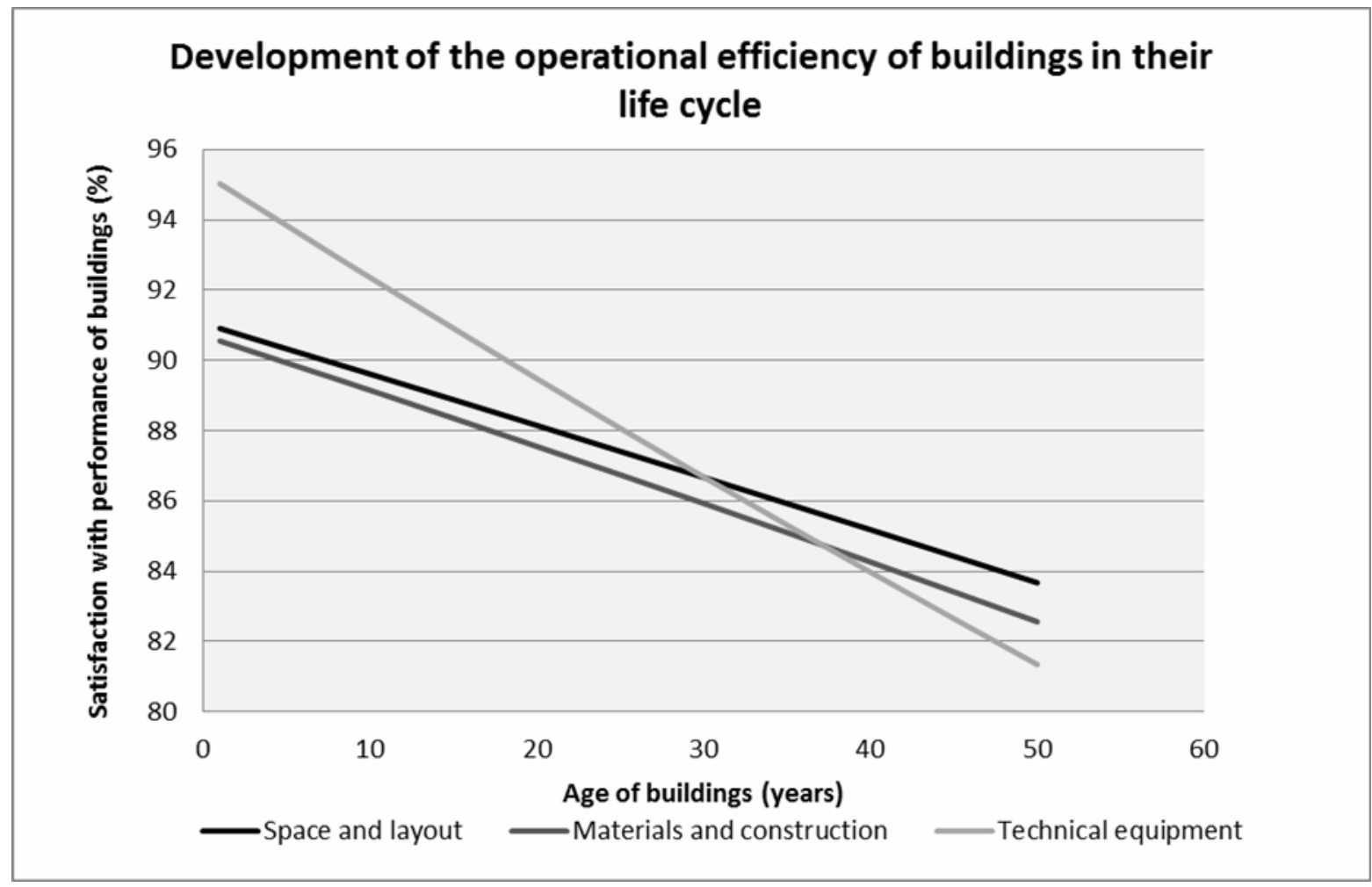

Figure 1: Development of the operational efficiency of buildings in their life cycle

From the graphic representation the average values of selected equations regression functions, it is evident that the initial (after the first year of use) OE for space layout and materials and construction solution of buildings is at around $90-91 \%$, and most positively evaluated is the quality of the technical equipment of buildings, it's approximately $95 \%$. The nearest clash of these three components are at getting around 30 - 40 years from built, where all three components are around $86 \%$. From this point, the descent is in the technical equipment solution greater degree than the other two constituents. The longest value is retaining space layout solution. 
Life and economic efficiency of buildings of a commercial nature is set at approximately 50 years [14], where it can be seen that the dissatisfaction with the performance of these building objects at this age is already relatively high.

\section{Conclusion}

The survey, which was made and evaluated represents only a small fraction of the amount of buildings and captures the views of individual employees in the field of FM, of buildings where respondents operate. Results of the evaluation were assessed by means of regression analysis, in terms of satisfaction with space layout, materials and construction and technical equipment of buildings. The resulting values were assessed on the value one, which can be defined as the current value after the first year of use - one year after final inspection of object. And this value should be relatively comparable to that resulting from the project documentation quality solution. During construction, this rate should be no longer significant change, respectively there should be no significant changes of the project documentation.

Currently the FM sector is among the fastest growing sectors in services, which can contribute in the future to support for addressing the transmission and application knowledge of facility management in construction projects. This article focuses on the transfer and application knowledge of facility management in construction projects where it is possible to consider about continuous integrated project delivery (IPD). In practice, following the issuance of project documentation, even better, get to a specialist who will evaluate it and in terms of management and maintenance, while at the concept of IPD, we assume the active participation of facility management in the process of drafting project documentation of buildings.

\section{Acknowledgements}

The article presents a partial research result of project VEGA - 1/0677/14 "Research of construction efficiency improvement through MMC technologies".

\section{References}

[1] Kozlovská, M. (2011). Nové trendy v realizácii stavieb - 2011. Eurostav. Volume 17,Issue 4, pp 12-15.

[2] Kozlovská, M. (2013). Innovations on integrated design and management of construction projects. In Multi-dimensional approaches supporting integrated design and management of construction project. Proceedings of scientific papers 2013. Košice, TU, 2013 pp. 6-13.

[3] Rajnoha, P. (2006) Úloha facility manažéra vo fáze obstarania stavebného objektu, In Facility management 2006. Zborník prednášok zo 4. Konferencie so zahraničnou účast’ou.

[4] Kozlovská, M., Šoltés, T. (2013). Construction projects creating tools, In: Integrated design and management of construction projects, Košice: TU, 2013 pp. 5-17.

[5] Uhrin, D. (2006). Priestorový manažment ako súčast’ facility managementu. Študentská vedecká konferencia, Stavebná fakulta, 2006.

[6] Somorová, V. (2010). ÚDRŽBA BUDOV facility management STUBA, Bratislava. 
[7] Somorová, V. (2009) FACILITY MANAGEMEN. Slovenská technická univerzita v Bratislave, Nakladatel'stvo STU.

[8] Daniels, K.(2003). Technika budov (príručka pre architektov a projektantov), Vydavatel'stvo: Jaga group, v.o.s., Bratislava.

[9] Sojková, Z.(2007) http://eldum.phil.muni.cz/mod/resource/view.php?id=1871, [4.6.2014].

[10] Török, CS. (1992). Úvod do teórie pravdepodobnosti a matematickej štatistiky. TUKE, Stavebná fakulta, Košice

[11] Armstrong, J.S. (2012). Illusions in Regression Analysis, International Journal of Forecasting (forthconing). Volume 28, Issue 3, July-September 2012, Pp 689-694 http://www.sciencedirect.com/science/article/pii/S0169207012000246, [4.6.2014].

[12] Freedman, D. A. (2005). Statistical Models: Theory and Practice, Cambridge University Press.

[13] Cook, R. D., Sanford, W. (1982). Criticism and Influence Analysis in Regression, Sociological Methodology, Vol. 13. pp. 313-361.

[14] Teicholz, E. (2001) Facility Design and Management Handbook. McGraw-Hill Professional. 1 edition. 